\title{
Bacillus subtilis natto: a non-toxic source of poly- $\gamma$-glutamic acid that could be used as a cryoprotectant for probiotic bacteria
}

\author{
Aditya R Bhat ${ }^{1}$, Victor U Irorere ${ }^{1}$, Terry Bartlett ${ }^{1}$, David Hill ${ }^{1}$, Gopal Kedia', Mark R Morris ${ }^{1}$, \\ Dimitris Charalampopoulos ${ }^{2}$ and Iza Radecka ${ }^{1 *}$
}

\begin{abstract}
It is common practice to freeze dry probiotic bacteria to improve their shelf life. However, the freeze drying process itself can be detrimental to their viability. The viability of probiotics could be maintained if they are administered within a microbially produced biodegradable polymer - poly- $\gamma$-glutamic acid ( $\gamma-P G A)$ - matrix. Although the antifreeze activity of $y-P G A$ is well known, it has not been used for maintaining the viability of probiotic bacteria during freeze drying. The aim of this study was to test the effect of $y$-PGA (produced by B. subtilis natto ATCC 15245) on the viability of probiotic bacteria during freeze drying and to test the toxigenic potential of $B$. subtilis natto. 10\% Y-PGA was found to protect Lactobacillus paracasei significantly better than $10 \%$ sucrose, whereas it showed comparable cryoprotectant activity to sucrose when it was used to protect Bifidobacterium breve and Bifidobacterium longum. Although $y-P G A$ is known to be non-toxic, it is crucial to ascertain the toxigenic potential of its source, $B$. subtilis natto. Presence of six genes that are known to encode for toxins were investigated: three component hemolysin ( $h b / D / A)$, three component non-haemolytic enterotoxin (nheB), B. cereus enterotoxin $T$ (bceT), enterotoxin FM (entFM), sphingomyelinase (sph) and phosphatidylcholine-specific phospholipase (pip/c). From our investigations, none of these six genes were present in B. subtilis natto. Moreover, haemolytic and lecithinase activities were found to be absent. Our work contributes a biodegradable polymer from a non-toxic source for the cryoprotection of probiotic bacteria, thus improving their survival during the manufacturing process.
\end{abstract}

Keywords: Probiotics; Y-PGA; Cryoprotectant; Toxicity; Bifidobacteria; Lactobacillus

\section{Introduction}

Over the years, extensive research has been done to determine the efficacy of probiotic foods in controlling and alleviating disorders/diseases (de Moreno de LeBlanc et al. 2007, Falagas et al. 2007, Garrait et al. 2009, LaraVilloslada et al. 2007). Probiotic bacteria are helpful in maintaining a healthy gut and have been used for controlling several types of gastrointestinal infections (Anukam et al. 2008, Benchimol and Mack 2004, Kligler et al. 2007, Lara-Villoslada et al. 2007, Park et al. 2007, Pochapin 2000, Szymanski et al. 2006). Some lactic acid bacteria have been shown to have antitumor activity (de LeBlanc et al. 2005). Research has also shown a marked reduction in total serum cholesterol in human

\footnotetext{
* Correspondence: i.radecka@wlv.ac.uk

'University of Wolverhampton, Wolverhampton, UK

Full list of author information is available at the end of the article
}

volunteers after ingestion of Enterococcus faecium (EF) M-74 enriched with selenium (Hlivak et al. 2005). Furthermore, strains of Lactobacillus and Bifidobacterium have been shown to cure dental disorders (Allaker and Douglas 2009). Because of these beneficial effects, probiotic microorganisms have been introduced into a variety of food and drink products for administration to humans or animals. Various strains of Lactobacillus and Bifidobacterium are used commonly as probiotic bacteria to benefit the health of the host (Benno and Mitsuoka 1992, de LeBlanc et al. 2005, De Simone et al. 1992, Kailasapathy and Rybka 1997).

One of the most important manufacturing steps for producing a probiotic food product is to introduce the bacteria into the foodstuff as dry cultures. Working with dry cultures is advantageous since they are easier to handle and have a longer shelf life than wet cultures. Freeze 
drying has been used most commonly for producing dry bacterial powders. However, the methods for preparation of freeze dried probiotic bacteria are often detrimental to the cell structure and viability (Saarela et al. 2005). Previously, it has been shown that the viability of lactic acid bacteria reduces by $3 \mathrm{log}$ CFU/g when freeze dried (Jagannath et al. 2010). Therefore, there remains a need to improve the viability of probiotic microorganisms as they pass through, in particular, the freeze drying process.

This research uses bacterial poly- $\gamma$-glutamic acid $(\gamma$-PGA) for protecting probiotic bacteria during freeze drying. $\gamma$-PGA is a non-toxic, non-immunogenic and biodegradable biopolymer that is produced by bacteria for use in various applications. $\gamma$-PGA is edible and is present in a traditional Japanese dish Natto which is made by fermenting soyabean with Bacillus strains. Most commonly, strains of Bacillus subtilis and Bacillus licheniformis have been researched for its production (Buescher and Margaritis 2007, Candela and Fouet 2006, Shih and Van 2001). Although the antifreeze properties of $\gamma$-PGA have been determined (Mitsuiki et al. 1998, Shih et al. 2003), it has never been used to protect live probiotic bacteria during freeze drying. This research was designed to analyse the effect of different concentrations of $\gamma$-PGA as a cryoprotectant for probiotic bacteria during freeze drying. The cryoprotective effect of the polymer produced by $B$. subtilis natto was investigated by assessing the viability of several probiotic bacteria (Lactobacillus paracasei, Bifidobacterium breve and Bifidobacterium longum) during freeze drying.

Whilst $\gamma$-PGA is suggested to be non-toxic and nonimmunogenic (Bajaj and Singhal 2011), it is important to ascertain the toxigenic potential of the specific bacterium used to produce the polymer for a novel food application (SCAN 2000). Consequently, B. subtilis natto was also screened for genes encoding toxins in other members of Bacillus sp. (Matarante et al. 2004). The presence/absence of haemolytic and lecithinase activities in this bacterium was also determined. Therefore, this research not only assesses the potential of $\gamma$-PGA as a cryoprotectant for probiotic bacteria, but also ascertains the toxigenic potential of its source, B. subtilis natto.

\section{Material and methods}

\section{Poly- $\gamma$-glutamic acid ( $\gamma$-PGA)}

$\gamma$-PGA (MW: 257,000 Da) was produced and extracted from B. subtilis natto ATCC 15245 and identified by Fourier transform infrared (FTIR) spectroscopy as reported earlier (Kedia et al. 2010).

\section{Bacterial strains}

Three probiotic bacteria (Bifidobacterium longum NCIMB 8809, Bifidobacterium breve NCIMB 8807 and Lactobacillus paracasei NCIMB 8835) were obtained from National Collection of Industrial and Marine Bacteria (NCIMB), Aberdeen, UK. The stock cultures were freeze-dried and stored at $-20^{\circ} \mathrm{C}$. Before use, the cultures were revived aseptically and grown anaerobically on Bifidobacteria Selective Medium (BSM) Agar for Bifidobacteria and MRS agar for Lactobacillus at $37^{\circ} \mathrm{C}$ in anaerobic gas jars using an atmosphere generation system (Oxoid Anaerogen ${ }^{\mathrm{Tm}}$, UK) and indicator strip according to manufacturer's instructions. Both BSM and MRS broth/agar were purchased from Sigma-Aldrich, U.K. and prepared according to the manufacturer's protocol.

\section{Growth media}

BSM agar/broth were used for the growth and enumeration of Bifidobacteria under study (Nualkaekul et al. 2011) and MRS medium was used for Lactobacillus.

\section{$\gamma$-PGA as a cryoprotectant}

Initially, unsterilised $\gamma$-PGA was used for preliminary cryoprotection experiment. However, due to potential concerns on the safety of future products, $\gamma$-PGA was sterilised by autoclaving at $110^{\circ} \mathrm{C}$ and 0.35 bar for $30 \mathrm{~min}$ before being used for cryoprotection studies. The structural integrity of the polymer was determined by comparing the FTIR spectra (Genesis II FTIR ${ }^{\mathrm{m}}$, UK) of the polymer before and after sterilization.

To prepare cells for freeze drying, all microorganisms were cultured anaerobically at $37^{\circ} \mathrm{C}$. B. breve and $B$. longum were cultured in $250 \mathrm{ml}$ of BSM broth for $22 \mathrm{~h}$ and 16 h respectively, while $L$. paracasei was cultured in $250 \mathrm{ml}$ of MRS broth for $48 \mathrm{~h}$. After incubation, viable counts were performed on BSM agar (Bifidobacteria) and MRS agar (Lactobacillus) to determine the number of viable cells prior to freeze drying. The cultures were centrifuged and washed with PBS to obtain cell pellets and then resuspended in $10 \mathrm{ml}$ solutions of either $10 \%(\mathrm{w} / \mathrm{v})$ $\gamma$-PGA, 5\% (w/v) $\gamma$-PGA or $10 \%(w / v)$ sucrose. For cells without a cryoprotectant, $10 \mathrm{ml}$ of sterile distilled water was added. The suspensions were incubated at room temperature for $1 \mathrm{~h}$ and then frozen at $-80^{\circ} \mathrm{C}$ for $24 \mathrm{~h}$. The frozen cultures were then freeze dried (Edwards Freeze Dryer Modulyo) at $-40^{\circ} \mathrm{C}$ and 5 mbar for $48 \mathrm{~h}$. After freeze drying, $10 \mathrm{ml}$ of PBS was added to each treatment and the viability was determined. Cells were enumerated by the Miles and Misra technique which involves a 10 fold dilution series in PBS followed by aseptically plating out $20 \mu \mathrm{l}$ of each cell suspension in triplicate on appropriate media, which were then incubated anaerobically at $37^{\circ} \mathrm{C}$.

\section{Scanning electron microscopy (SEM) analysis}

SEM analysis was performed to determine the surface structure of freeze dried cells protected with $\gamma$-PGA. All freeze dried samples were coated with gold using a sputter 
coater (Emscope Sc 500). SEM analysis was performed using a Zeiss EVO50 and the images analysed using the Smart SEM software.

\section{Toxigenic analysis}

The presence of major enterotoxins and virulence factors in $B$. subtilis natto was investigated and compared to $B$. cereus which was used as a positive control (Matarante et al. 2004). The genes encoding various enterotoxins and enzymes screened were: HBL - a three component hemoly$\sin (h b l D / A)$, NHE - three component non-haemolytic enterotoxin (nheB), B. cereus enterotoxin $\mathrm{T}$ (bceT), enterotoxin FM (entFM), sphingomyelinase (sph), phosphatidylinositol and phosphatidylcholine specific phospholipase (piplc). Phosphofructokinase A ( $p f k A)$, a housekeeping gene, was used as positive control.

\section{DNA isolation and purification}

$5 \mathrm{ml}$ of Tryptone Soya Broth was inoculated with a single colony of B. subtilis natto or B. cereus and the cultures were incubated at $30^{\circ} \mathrm{C}$ overnight with shaking at $150 \mathrm{rpm}$. Bacterial cells were harvested by centrifugation at $1,000 \times \mathrm{g}$ for $5 \mathrm{~min}$ and the bacterial pellets were washed with sterile water. DNA was isolated using the GenElute Bacterial Genomic DNA kit (Sigma-Aldrich, UK) according to the protocol provided by the manufacturer. The DNA quantity was determined using a Nanodrop2000 Spectrophotometer (Thermo Scientific, UK).

\section{$P C R$ analysis}

The primers for PCR analysis were purchased from Sigma-Aldrich, UK. The details of the primers used for screening the genes of interest are provided in Table 1. The gene sequence of $p f k A$ was obtained from the nucleotide collection of the National Centre for Biotechnology Information (NCBI) and the primers for the gene were designed using the NCBI Primer-Blast. PCR analysis was performed on isolated and purified DNA from each microorganism as described by (Matarante et al. 2004). Amplification comprised of an initial denaturation at $94^{\circ} \mathrm{C}$ for $3 \mathrm{~min}$ followed by 31 cycles of denaturation $\left(94^{\circ} \mathrm{C}\right.$ for $30 \mathrm{~s})$, annealing $\left(58^{\circ} \mathrm{C}\right.$ for $\left.45 \mathrm{~s}\right)$ and extension $\left(72^{\circ} \mathrm{C}\right.$ for $1 \mathrm{~min} 30 \mathrm{~s}$ ). A final extension at $72^{\circ} \mathrm{C}$ for $5 \mathrm{~min}$ was also performed. Control mixtures without template DNA were also included in each experiment. PCR amplification was carried out in an MJ Research PTC-200 Peltier Thermal Cycler. Taq polymerase, deoxynucleotide triphosphates and DNA molecular weight markers were purchased from Roche, UK. The amplified fragments were separated by electrophoresis on a $2 \%$ agarose gel.

\section{Determination of haemolytic and lecithinase activities} Haemolytic and lecithinase activies were determined using a method described previously (Matarante et al.
2004). Haemolytic activity was determined at $30^{\circ} \mathrm{C}$ on blood agar plates containing $5 \%$ horse blood. Lecithinase (phosphatidylinositol-specific phospholipase C) activity was determined at $30^{\circ} \mathrm{C}$ on nutrient agar supplemented with $8 \%$ egg yolk emulsion. B. cereus was used as a positive control. $5 \mu \mathrm{l}$ of overnight TSB cultures of both microorganisms incubated at $37^{\circ} \mathrm{C}$ were used to inoculate each of the media plates in triplicate. The cell-free supernatants of each microorganism were also tested for their haemolytic and lecithinase activities by inoculating $5 \mu \mathrm{l}$ of each cell free supernatants into the aforementioned media (Matarante et al. 2004).

\section{Statistical analyses}

All results were statistically analysed using Microsoft Excel 2010 and GraphPad Prism 5. Two-factor Anova and student's $T$ test were used to compare data. The Bonferroni multiple comparison test was used for the non-parametric analysis of the data to determine the difference between individual groups in a data set. $\mathrm{P}$ value $\leq 0.05$ was considered to be statistically significant.

\section{Results}

\section{$\gamma$-PGA as a cryoprotectant for probiotic bacteria}

The effect of sterilization on $\gamma$-PGA was investigated using FTIR to determine whether steam sterilization alters the structure of the polymer. Results from FTIR spectroscopy (Figure 1) indicated that the FTIR spectra for sterilised and unsterilised polymer showed all the peaks representing the characteristic bonds in $\gamma$-PGA. This indicates that steam sterilisation does not alter the chemical integrity of the polymer.

$10 \% \gamma$-PGA, 5\% $\gamma$-PGA and 10\% sucrose were used to protect probiotic bacteria during freeze drying and the effect of cryoprotection was assessed (Figure 2). It was observed that when no cryoprotectant was used to protect the cells, $L$. paracasei showed a reduction in viability of $1.34 \log \mathrm{CFU} / \mathrm{ml}$. When $10 \%$ sucrose was used to protect $L$. paracasei during freeze drying, $0.91 \mathrm{log}$ $\mathrm{CFU} / \mathrm{ml}$ reduction in viability was observed after freeze drying. However, for $10 \% \gamma$-PGA-protected cells, the loss in viability was reduced to $0.51 \log \mathrm{CFU} / \mathrm{ml}$. For $L$. paracasei, $10 \% \gamma$-PGA was able to protect the cells significantly $(\mathrm{P} \leq 0.05)$ better than $10 \%$ sucrose. The cryoprotectant ability of $5 \% \gamma$-PGA (Figure 2) was comparable to $10 \%$ sucrose $(\mathrm{P}>0.05)$. A more pronounced reduction in viability $(\sim 2.5 \log \mathrm{CFU} / \mathrm{ml})$ was observed when both Bifidobacterium strains were freeze dried without any cryoprotectant (Figure 2). When the cells were protected with $10 \% \gamma$-PGA, only $1.24-1.26 \mathrm{log}$ $\mathrm{CFU} / \mathrm{ml}$ reduction in viability was observed. The cryoprotectant ability of $10 \%$ sucrose and $10 \% \gamma$-PGA for the Bifidobacterium strains was comparable $(\mathrm{P} \geq 0.05)$. 
Table 1 PCR primers used and virulence factors (adapted from Matarante et al. 2004)

\begin{tabular}{|c|c|c|c|c|}
\hline Target gene & Primer name & Primer sequence $\left(5^{\prime}-3^{\prime}\right)$ & Amplicon size (bp) & Reference \\
\hline \multirow[t]{2}{*}{$h b l-D / A$} & hblD-f & GGAGCGGTCGTTATTGTTGT & 623 & (Matarante et al. 2004) \\
\hline & hblA-r & GCCGTATCTCCATTGTTCGT & & \\
\hline \multirow[t]{2}{*}{ nheB } & nheB $1500 \mathrm{~S}$ & CTATCAGCACTTATGGCAG & 769 & (Matarante et al. 2004) \\
\hline & nhe B 2269 A & ACTCCTAGCGGTGTTCC & & \\
\hline \multirow[t]{2}{*}{ bcet } & ETF & TTACATTACCAGGACGTGCTT & 428 & (Matarante et al. 2004) \\
\hline & ETR & TGTTGTGATTGTAATTCAGG & & \\
\hline \multirow[t]{2}{*}{ entFM } & EntA & ATGAAAAAAGTAATTTGCAGG & 1269 & (Matarante et al. 2004) \\
\hline & EntB & TTAGTATGCTTITGTGTAACC & & \\
\hline \multirow[t]{2}{*}{ sph } & $\mathrm{Ph} 1$ & CGTGCCGATTTAATTGGGGC & 558 & (Matarante et al. 2004) \\
\hline & $\mathrm{Ph} 2$ & CAATGTTTAAACATGGATGCG & & \\
\hline \multirow[t]{2}{*}{ piplc } & PC105 & CGCTATCAATGGACCATGG & 569 & (Matarante et al. 2004) \\
\hline & PC106 & GGACTATTCCATGCTGTACC & & \\
\hline \multirow[t]{2}{*}{$p f k A^{*}$} & pfkA-F & CCATCAGCTAAACCAGCC & 370 & This study \\
\hline & pfkA-R & CGCGGTGGTACGAAATTA & & \\
\hline
\end{tabular}

* pfkA primer was designed using the NCBI Primer-Blast.

\section{SEM analysis}

Freeze dried bifidobacteria with and without $\gamma$-PGA as a cryoprotectant were analysed using SEM to understand how the cells may be protected. As is evident from Figure $3 \mathrm{a}$ and $\mathrm{b}$, freeze dried B. longum cells protected with $\gamma$-PGA appear to be encapsulated within a material, suggesting cluster of cells within a $\gamma$-PGA matrix. The thickness of $\gamma$-PGA coating could be potentially calculated with further testing using transmission electron microscopy (TEM).

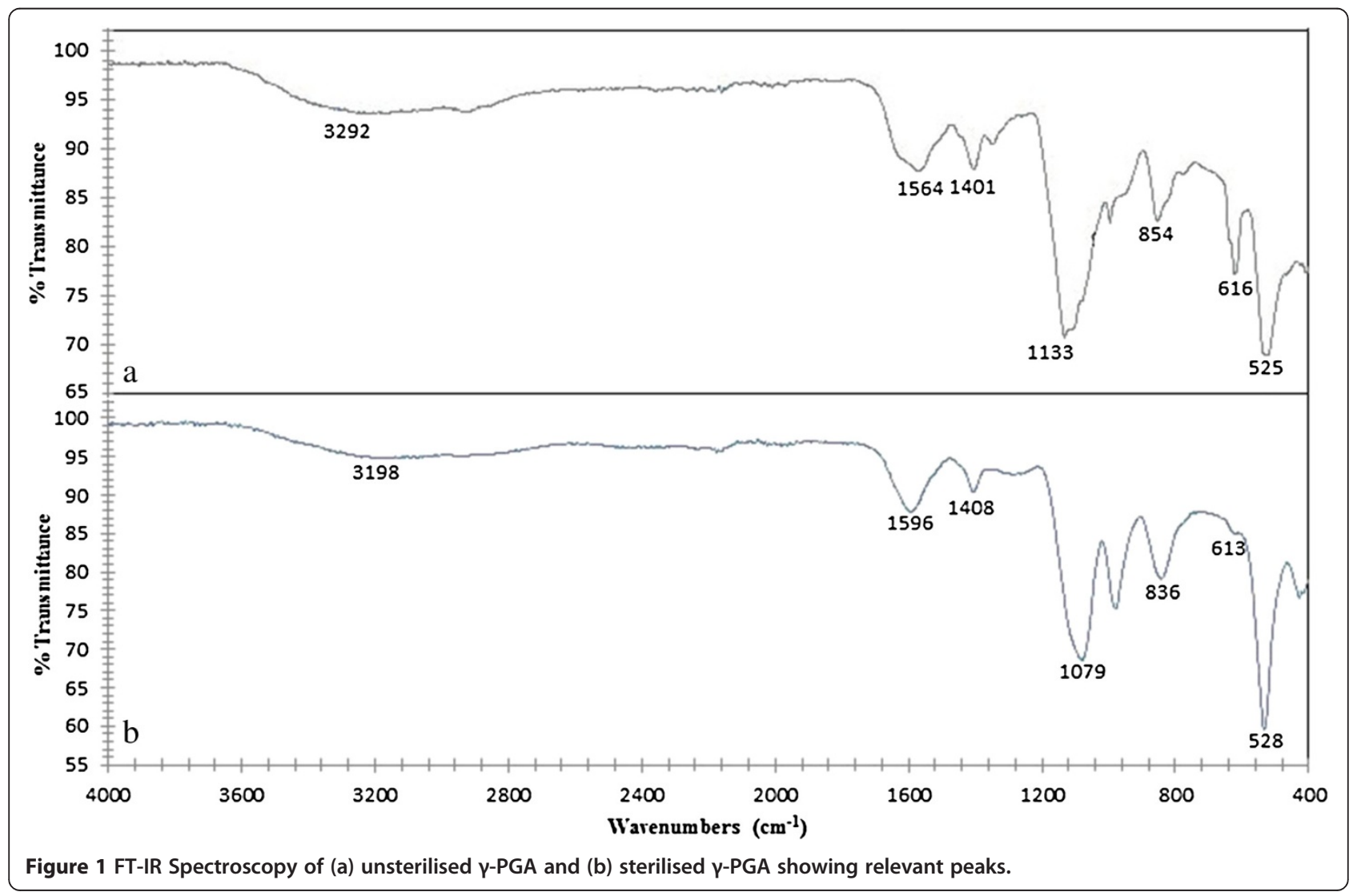




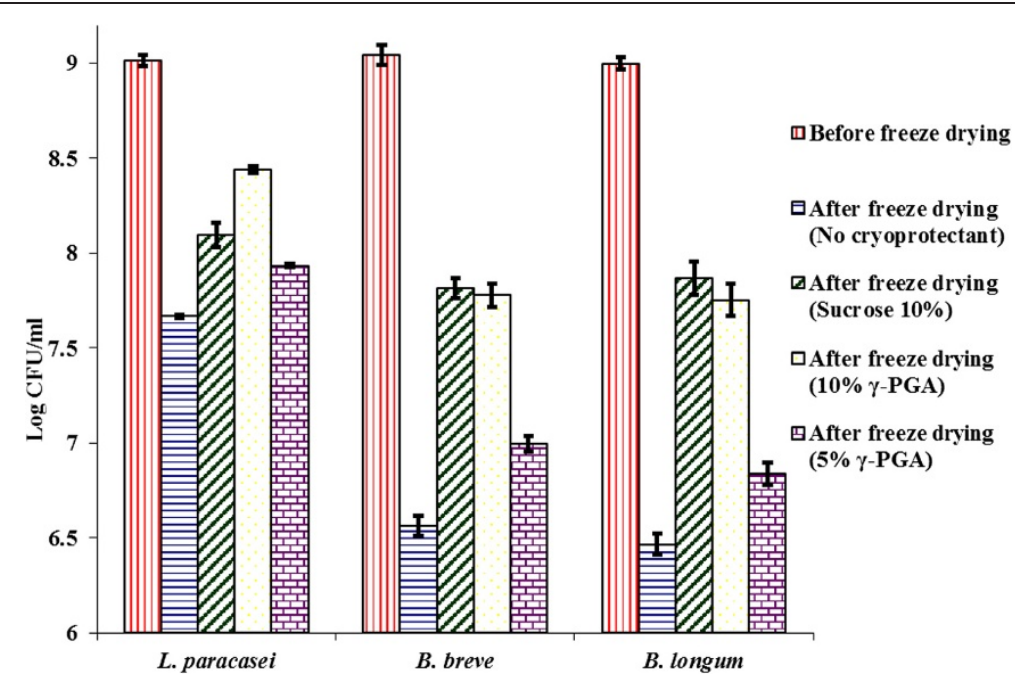

Figure 2 Effect of $\mathrm{\gamma}$-PGA and sucrose on viability of probiotic bacteria during freeze drying. Cells were freeze dried at $-40^{\circ} \mathrm{C}$ and $5 \mathrm{mbar}$ pressure and viability was measured before and after freeze drying on BSM agar. Experiments were conducted in triplicate $(n=3)$.

\section{Screening of $B$. subtilis for toxin genes using PCR}

The housekeeping gene $p f k A$ was seen to be present in both DNA extracts of $B$. subtilis natto and $B$. cereus, confirming successful DNA extraction and PCR amplification (Figure 4). Of the six genes coding for toxin production, four (nheB, entFM, sph, piplc) were present in the control organism B. cereus (Figure 4). However none of these six genes were present in B. subtilis natto. No band was seen in any of the negative control experiments lacking DNA.
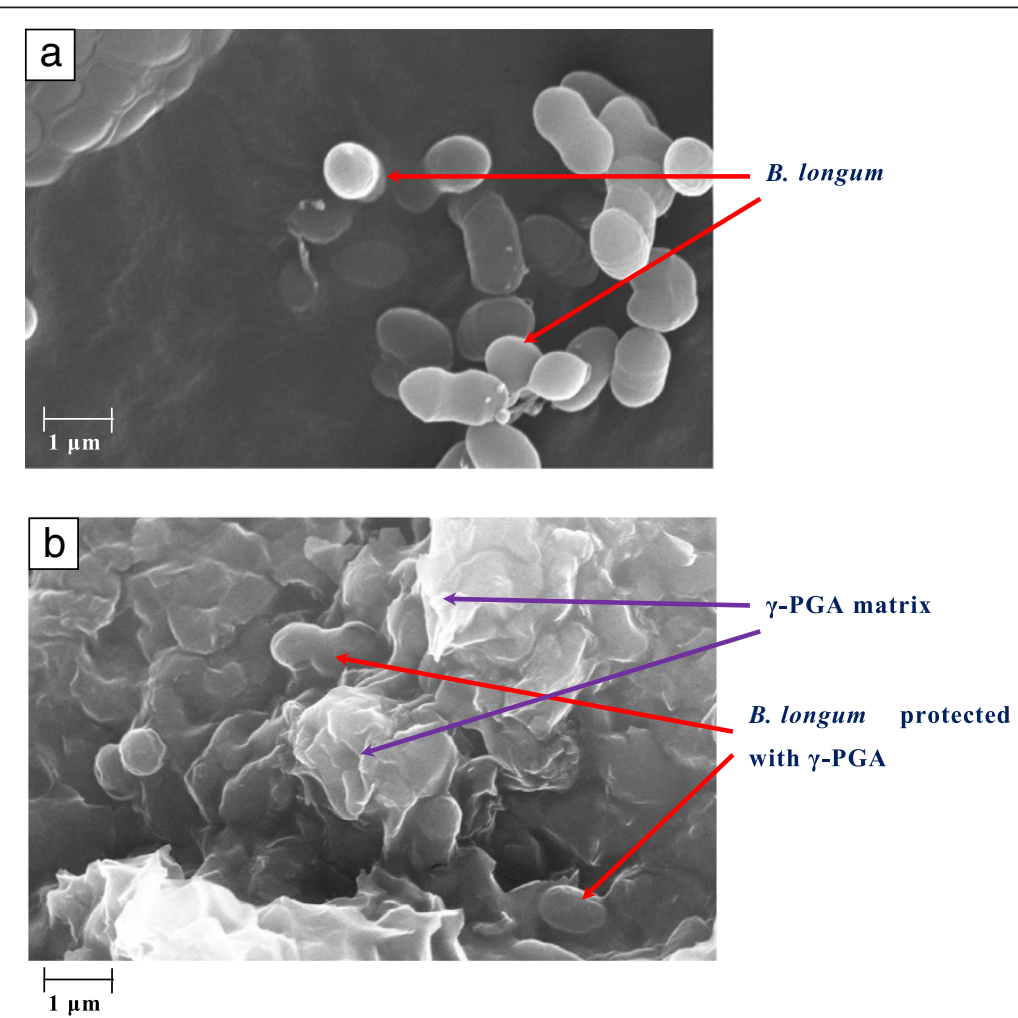

Figure $3 \mathrm{SEM}$ image of a) Freeze dried $B$. longum cells with no $\gamma$-PGA protection (EHT $=20.00 \mathrm{kV}$; Signal $A=S E 1 ; W D=4.0 \mathrm{~mm}$ ) b) Freeze dried $B$. longum protected with $\gamma$-PGA (EHT $=\mathbf{2 0 . 0 0 ~ k V ; ~ S i g n a l ~ A ~ = ~ S E 1 ; ~ W D ~ = ~} 4.5 \mathrm{~mm}$ ). SEM analysis was performed using Zeiss EVO50, U.K. and photographs were analysed using the software provided by Zeiss EVO50. 


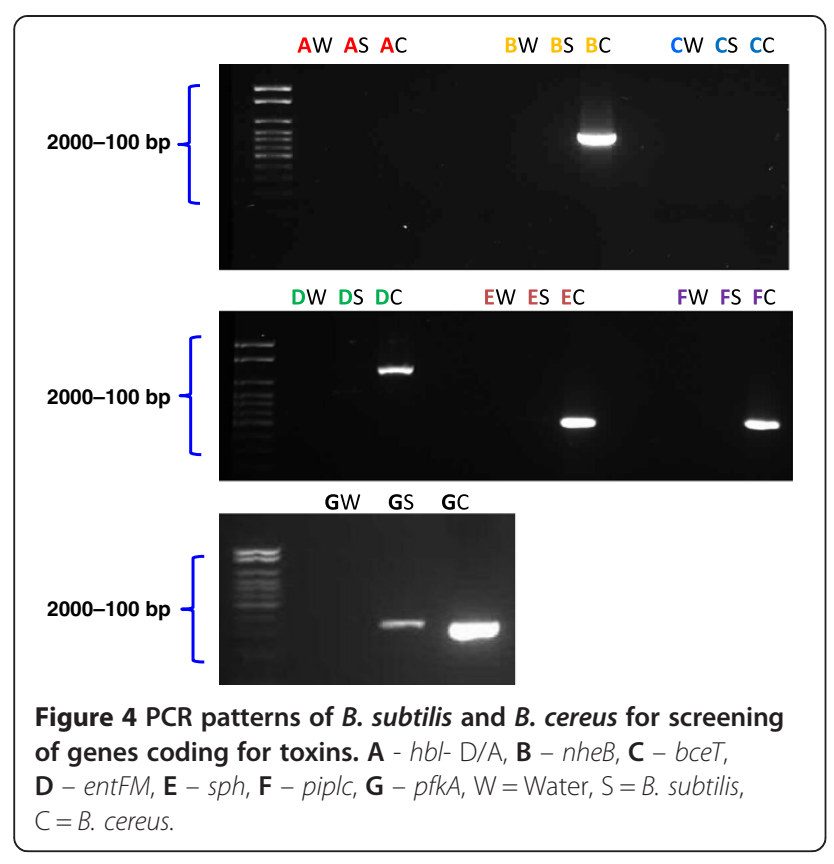

\section{Haemolytic and lecithinase activities of $B$. subtilis}

$B$. subtilis natto and $B$. cereus (positive control) were tested for haemolytic (Figure 5a and b) and lecithinase (Figure 5c \& d) activities on blood agar plates and nutrient agar, supplemented with 8\% egg yolk emulsion. Large and clear halo formation was seen around the colonies of $B$. cereus on both agars, thus confirming that this bacterium exhibits haemolytic and lecithinase activities (Figure 5). In contrast, no halo formation was seen around the colonies of $B$. subtilis natto, indicating that this bacterium does not exhibit haemolytic or lecithinase activity. The cell-free supernatants of both these bacteria showed similar results.

\section{Discussion}

The antifreeze activity of $\gamma$-PGA has been assessed previously (Mitsuiki et al. 1998, Mizuno et al. 1997,
Shih et al. 2003). However, it has never been used to maintain and protect the viability of bacteria. This study is the first to assess the effect of $\gamma$-PGA on the viability of probiotic bacteria during freeze drying.

On conclusion of the cryoprotectant tests, it was seen that $L$. paracase $i$ was more resilience to the freeze drying process than both the Bifidobacterium strains under study, since there was only $1.34 \log \mathrm{CFU} / \mathrm{ml}$ reduction in viability of unprotected $L$. paracase $i$ when they were freeze dried, whereas the unprotected Bifidobacterium strains showed a reduction in viability of around $2.5 \mathrm{log}$ $\mathrm{CFU} / \mathrm{ml}$ (Figure 2). Wang et al. (2004) found that Streptococcus thermophilus and Lactobacillus acidophilus exhibited greater survival during freeze drying than did B. longum and B. infantis (Wang et al. 2004). In contrast, Heidebach et al. (2010) found that probiotic Bifidobacterium Bb12 survived better than Lactobacillus F19 (Heidebach et al. 2010). Otero et al. (2007) studied the effect of freeze drying on different Lactobacillus species and found considerable variation in survival between species and even strains of the same species (Otero et al. 2007). Similar results have been found for members of Bifidobacterium species and strains (Lian et al. 2002). Based on the above, it could be concluded that resistance to the freeze drying process varies between species and even strains of the same species. This study demonstrates that $L$. paracase $i$ is more resistant to the freeze drying process than B. longum and B. breve.

The results for freeze drying with $\gamma$-PGA as a cryoprotectant showed that for L. paracasei, sterilised $10 \%$ $\gamma$-PGA could protect the cells during freeze drying significantly better than $10 \%$ sucrose $(\mathrm{P}<0.05)$. Although $5 \% \gamma$-PGA was also able to protect the cells during freeze drying as efficiently as sucrose $(\mathrm{P}>0.05)$, it was not as efficient as $10 \% \gamma$-PGA. For $B$. longum and $B$. breve, $10 \%$ sterilised $\gamma$-PGA and $10 \%$ sucrose were equally efficient in maintaining viability during freeze drying $(\mathrm{P}>0.05)$.

It was also observed that the sterilised $\gamma$-PGA (obtained by autoclaving an aqueous solution of $\gamma$-PGA)

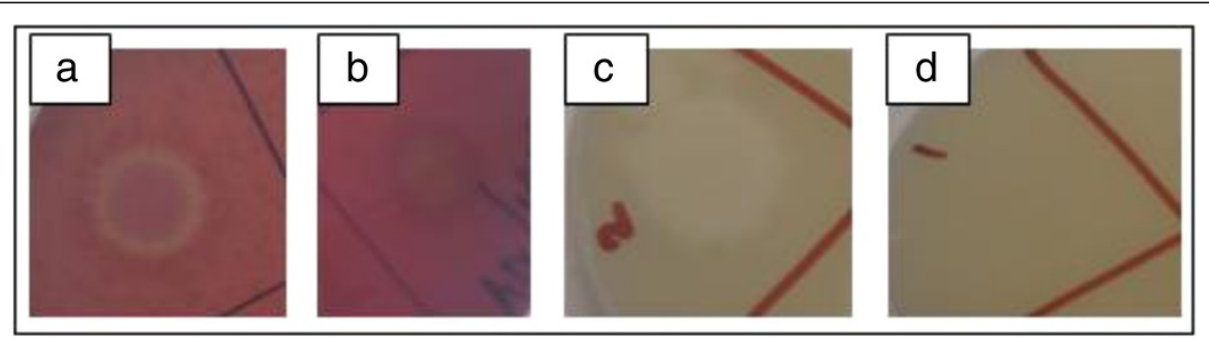

Figure 5 Physiological analysis of the haemolytic and lecithinase activities of $B$. subtilis natto and $B$. cereus: a - B. cereus haemolytic activity showing halo around the cells, $b-B$. subtilis natto haemolytic activity with no halo observed around the cells, $c$ : $B$. cereus lecithinase activity with halo indicating the presence of lecithinase action, $d-B$. subtilis natto lecithinase activity test without halo, indicating the absence of lecithinase activity. 
was a better cryoprotectant than unsterilised polymer which was initially used for preliminary cryoprotection analysis (results not shown). It has been shown that heating an aqueous solution of $\gamma$-PGA can reduce its molecular weight (Goto and Kunioka 1992). Previous studies have also demonstrated that $\gamma$-PGA with a lower molecular weight has a higher antifreeze activity than a high molecular weight polymer (Mitsuiki et al. 1998, Shih et al. 2003). This may explain why sterilising $\gamma$-PGA enhanced its cryoprotectant ability. FTIR analysis revealed that the structural integrity of the polymer remained intact after steam sterilization (Figure 1). This is in agreement with the study done by Goto and Kunioka (1992) which suggested that the activation energy of the polymer chain scission due to steam sterilization of $\gamma$-PGA by heating is approximately $120 \mathrm{~kJ} / \mathrm{M}$ (Goto and Kunioka 1992). The relative bond strengths of the $\mathrm{C}-\mathrm{C}, \mathrm{C}-\mathrm{N}$ and $\mathrm{C}-\mathrm{O}$ bonds are greater than $300 \mathrm{~kJ} / \mathrm{M}$, hence, the breaking of the bonds by heating at $110^{\circ} \mathrm{C}$ is unexpected.

It has been found that sucrose offers better protection during freeze drying of lactobacilli when compared to trehalose and sorbitol (Siaterlis et al. 2009). Since $\gamma-$ PGA could protect lactobacilli better than sucrose in this study, it could indicate that $\gamma$-PGA is a better cryoprotectant than trehalose and sorbitol as well. Nata, a bacterial cellulose produced by Acetobacter xylinum, has also been used to protect different lactobacilli during freeze drying (Jagannath et al. 2010). When the cells were immobilized using nata and freeze dried, it was observed that viable cell number decreased from $10^{9}-10^{10} \mathrm{CFU} / \mathrm{g}$ to $10^{7} \mathrm{CFU} / \mathrm{g}$. In this study, there was only a $0.51 \log \mathrm{CFU} / \mathrm{ml}$ and $1.3 \log \mathrm{CFU} / \mathrm{ml}$ reduction in the viability of $\gamma$-PGA-protected Lactobacilli and Bifidobacteria respectively (Figure 2), indicating that $\gamma$-PGA may be a better cryoprotectant compared to nata. However, the protection offered by $\gamma$-PGA, trehalose, sorbitol and nata during freeze drying of Lactobacilli needs to be directly compared under identical conditions.

Following the discovery and use of B. subtilis natto in the solid state fermentation of soybean to produce the common Japanese food natto, there has been a surge in the industrial application of Bacillus sp. for the production of a wide range of useful products (Schallmey et al. 2004). However the detection of toxins and the genes that produce them in some strains of Bacillus (Beattie and Williams 1999, Phelps and McKillip 2002) has questioned the use of Bacillus $s p$. in industrial production of several products, especially food and health products. There have been reports where the production of emetic toxins by different Bacillus sp., including $B$. subtilis isolated from food, water and food plants has been demonstrated (From et al. 2005).
However, it is important to note that the authors concluded that the tendency of toxin production in strains of Bacillus other than B. cereus isolated from food, water and food plants is rare. The occurrence of genes capable of producing toxins in other strains of Bacillus sp. has already prompted the Scientific Committee on Animal Nutrition (SCAN) to recommend that products from Bacillus sp. other than those from B. cereus group should be accepted only if there is no detection of toxin production (SCAN 2000). For other products of Bacillus sp. which do not include the whole microorganism, it has been recommended that the producing strain should be shown not to produce toxins under production conditions. Therefore, to make $\gamma$-PGA applicable in the probiotic food industry as a cryoprotectant, it was crucial to analyse the $\gamma$-PGA producing strain for the presence of genes that are known to produce toxins. Moreover, there is presently no report on the toxigenic potential of Bacillus subtilis natto, which was used for the production of $\gamma$-PGA in our study.

Therefore, the toxigenic potential of B. subtilis natto was assessed. The results of the toxigenic analysis in this study showed that none of the six genes known to produce toxins ( $h b l \mathrm{D} / \mathrm{A}, \mathrm{nheB}, \mathrm{bceT}$, entFM, sph, piplc) were present in B. subtilis natto. Also, physiological analysis showed the absence of haemolytic and lecithinase activities in $B$. subtilis natto. In contrast, the positive control $B$. cereus showed the presence of four of the genes (nheB, entFM, sph, piplc) and also exhibited both haemolytic and lecithinase activities. These results are similar to those obtained by (Matarante et al. 2004) who reported the absence of the genes ( $h b l \mathrm{D} / \mathrm{A}$, nheB, bceT, entFM, sph and piplc) in all the strains of Bacillus sp. isolated from sausages and more importantly in $B$. subtilis. Our results are in accordance with another study that investigated the cytotoxic potential of other strains of B. subtilis, B. licheniformis, B. cereus and B. amyloliquefaciens used in industrial production of enzyme products and discovered that none of the industrial strains demonstrated any in vitro cytotoxic activity (Pedersen et al. 2002).

In conclusion, this study has established that $\gamma$-PGA could be used successfully to improve the survival of probiotic bacteria when during freeze drying. Three probiotic bacteria (L. paracasei, B. longum, B. breve) were successfully protected with $\gamma$-PGA when they were freeze dried. It was also seen that Lactobacillus was more resistant to the freeze drying process than Bifidobacteria. While choosing an agent to protect probiotic bacteria, it is essential to choose one that protects them during the different stages of their production and upon incorporation into food products. Therefore, future work will involve studying the ability of $\gamma$-PGA to 
protect probiotic bacteria during storage in a foodstuff and during passage through the gastrointestinal tract.

For $\gamma$-PGA to be used in health and food products, it is important to analyse $\gamma$-PGA producing strains for the presence of genes that are known to produce toxins. This research successfully confirmed that B. subtilis natto, the bacterium used to produce $\gamma$-PGA for the novel application, does not contain any of the genes that are usually responsible for toxin production. In addition, the absence of haemolytic or lecithinase activity in $B$. subtilis natto was also demonstrated.

Therefore, this study suggests that $\gamma$-PGA could be used as a food ingredient for the delivery of probiotic bacteria.

\section{Competing interests}

The authors declare that they have no competing interests.

\section{Acknowledgments}

Many thanks to the University of Wolverhampton, School of Applied Sciences for their financial support and granting access to their laboratory facilities, without which this research could not have been carried out.

\section{Author details}

${ }^{1}$ University of Wolverhampton, Wolverhampton, UK. ${ }^{2}$ University of Reading, Reading, UK.

Received: 7 June 2013 Accepted: 3 July 2013

Published: 5 July 2013

\section{References}

Allaker RP, Douglas CWI (2009) Novel anti-microbial therapies for dental plaquerelated diseases. Int J Antimicrob Ag 33:8-13

Anukam KC, Osazuwa EO, Osadolor HB, Bruce AW, Reid G (2008) Yogurt containing probiotic Lactobacillus rhamnosus GR-1 and L. reuteri RC-14 helps resolve moderate diarrhea and increases CD4 count in HIV/AIDS patients. J Clin Gastroenterol 42:239-243

Bajaj I, Singhal R (2011) Poly(glutamic acid) - An emerging biopolymer of commercial interest. Bioresour Technol 102:5551-5561

Beattie SH, Williams AG (1999) Detection of toxigenic strains of Bacillus cereus and other Bacillus spp. with an improved cytotoxicity assay. Lett Appl Microbiol 28:221-225

Benchimol E, Mack D (2004) Probiotics in relapsing and chronic diarrhea. J Pediat Hematol Onc 26:515-517

Benno Y, Mitsuoka T (1992) Impact of Bifidobacterium longum on human fecal microflora. Microbiol Immunol 36:683-694

Buescher JM, Margaritis AM (2007) Microbial biosynthesis of polyglutamic acid biopolymer and applications in the biopharmaceutical, biomedical and food industries. Crit Rev Biotechnol 27:1-19

Candela T, Fouet A (2006) Poly-gamma-glutamate in bacteria. Mol Microbiol 60:1091-1098

de LeBlanc ADM, Matar C, LeBlanc N, Perdigón G (2005) Effects of milk fermented by Lactobacillus helveticus R389 on a murine breast cancer model. Breast Cancer Res 7:477-486

de Moreno de LeBlanc A, Matar C, Perdigón G (2007) The application of probiotics in cancer. Brit J Nutr 98:105-110

De Simone C, Clardi A, Grassi A (1992) Effect of Bifidobacterium bifidum and Lactobacillus acidophilus on gut mucosa and peripheral blood B lymphocytes. Immunotoxicol 14:331-340

Falagas ME, Betsi GE, Athanasiou S (2007) Probiotics for the treatment of women with bacterial vaginosis. Clin Microbiol Infec 13:657-664

From C, Pukall R, Schumann P, Hormazabal V, Granum PE (2005) Toxin-producing ability among Bacillus spp. outside the Bacillus cereus group. Appl Environ Microbiol 71:1178-1183

Garrait G, Jarrige JF, Blanquet-Diot S, Alric M (2009) Genetically engineered yeasts as a new delivery vehicle of active compounds to the digestive tract: In vivo validation of the concept in the rat. Metab Eng 11:148-154
Goto A, Kunioka M (1992) Biosynthesis and hydrolysis of poly(y-glutamic acid) from Bacillus subtilis IFO3335. Biosci Biotechnol Biochem 56:1031-1035

Heidebach T, Forst P, Kulozik U (2010) Influence of casein-based microencapsulation on freeze-drying and storage of probiotic cells. J Food Eng 98:309-316

Hlivak P, Odraska J, Ferencik M, Ebringer L, Jahnova E, Mikes Z (2005) One-year application of probiotic strain Enterococcus faecium M-74 decreases serum cholesterol levels. Bratisl Lek Listy 106:67-72

Jagannath A, Raju PS, Bawa AS (2010) Comparative evaluation of bacterial cellulose (nata) as a cryoprotectant and carrier support during the freeze drying process of probiotic lactic acid bacteria. LWT- Food Sci Technol 43:1197-1203

Kailasapathy K, Rybka S (1997) L. acidophilus and Bifidobacterium spp. - their therapeutic potential and survival in yogurt. Aust J Dairy Technol 52:28-33

Kedia G, Hill D, Hill R, Radecka I (2010) Production of poly- $\gamma$-glutamic acid by Bacillus subtilis and Bacillus licheniformis with different growth media. J Nanosci Nanotechnol 10:5926-5934

Kligler B, Hanaway P, Cohrssen A (2007) Probiotics in children. Pediatr Clin N Am 54:949-967

Lara-Villoslada F, Sierra S, Boza J, Xaus J, Olivares M (2007) Beneficial effects of consumption of a dairy product containing two probiotic strains, Lactobacillus coryniformis CECT5711 and Lactobacillus gasseri CECT5714 in healthy children. Nutr Hosp 22:496-502

Lian W-C, Hsiao H-C, Chou C-C (2002) Survival of bifidobacteria after spray-drying. Int J Food Microbiol 74:79-86

Matarante A, Baruzzi F, Cocconcelli PS, Morea M (2004) Genotyping and toxigenic potential of Bacillus subtilis and Bacillus pumilus strains occurring in industrial and artisanal cured sausages. Appl Environ Microbiol 70:5168-5176

Mitsuiki M, Mizuno A, Tanimoto H, Motoki M (1998) Relationship between the antifreeze activities and the chemical structures of oligo- and poly(glutamic acid)s. J Agric Food Chem 46:891-895

Mizuno A, Mitsuiki M, Toba S, Motoki M (1997) Antifreeze activities of various food components. J Agric Food Chem 45:14-18

Nualkaekul S, Salmeron I, Charalampopoulos D (2011) Investigation of the factors influencing the survival of Bifidobacterium longum in model acidic solutions and fruit juices. Food Chem 129:1037-1044

Otero M, Espeche M, Nader-Macias M (2007) Optimization of the freeze-drying media and survival throughout storage of freeze-dried Lactobacillus gasseri and Lactobacillus delbrueckii subsp. delbrueckii for veterinarian probiotic applications. Process Biochem 42:1406-1411

Park SK, Park DI, Choi JS, Kang MS, Park JH, Kim HJ, Cho YK, Sohn Cl, Jeon WK, Kim BI (2007) The effect of probiotics on Helicobacter pylori eradication. Hepato-gastroenterol 54:2032-2036

Pedersen PB, Bjornvad ME, Rasmussen MD, Petersen JN (2002) Cytotoxic potentia of industrial strains of Bacillus sp. Regul Toxicol Pharmacol 36:155-161

Phelps RJ, McKillip JL (2002) Enterotoxin production in natural isolates of Bacillaceae outside the Bacillus cereus group. Appl Environ Microbiol 68:3147-3151

Pochapin M (2000) The effect of probiotics on Clostridium difficile diarrhea. Am J Gastroenterol 95:S11-S13

Saarela M, Virkajärvi I, Alakomi H, Mattila-Sandholm T, Vaari A, Suomalainen T, Mättö J (2005) Influence of fermentation time, cryoprotectant and neutralization of cell concentrate on freeze-drying survival, storage stability, and acid and bile exposure of Bifidobacterium animalis ssp. lactis cells produced without milk-based ingredients. J Appl Microbiol 99:1330-1339

SCAN (2000) Opinion of the scientific committee on animal nutrition on the safety of use of Bacillus species in animal nutrition. European Commission, Health and Consumer Protection Directorate-General (SCAN) Scientific Committee on Animal Nutrition. Available at: http://ec.europa.eu/food/fs/sc/ scan/out41_en.pdf

Schallmey M, Singh A, Ward OP (2004) Developments in the use of Bacillus species for industrial production. Can J Microbiol 50:1-17

Shih I-L, Van Y-T (2001) The production of poly-(Y-glutamic acid) from microorganisms and its various applications. Bioresour Technol 79:207-225

Shih IL, Van YT, Sau YY (2003) Antifreeze activities of poly(-glutamic acid) produced by Bacillus licheniformis. Biotechnol Lett 25:1709-1712

Siaterlis A, Deepika G, Charalampopoulos D (2009) Effect of culture medium and cryoprotectants on the growth and survival of probiotic lactobacilli during freeze drying. Lett Appl Microbiol 48:295-301 

blind, placebo-controlled trial. Aliment Pharm Ther 23:247-253

Wang Y-C, Yu R-C, Chou C-C (2004) Viability of lactic acid bacteria and bifidobacteria in fermented soymilk aftery drying, subsequent rehydration and storage. Int J Food Microbiol 93:209-217

doi:10.1186/2191-0855-3-36

Cite this article as: Bhat et al:: Bacillus subtilis natto: a non-toxic source of poly- $\gamma$-glutamic acid that could be used as a cryoprotectant for probiotic bacteria. AMB Express 2013 3:36.

\section{Submit your manuscript to a SpringerOpen ${ }^{\circ}$} journal and benefit from:

- Convenient online submission

- Rigorous peer review

- Immediate publication on acceptance

- Open access: articles freely available online

- High visibility within the field

- Retaining the copyright to your article 